\title{
Article/Artigo
}

\section{Genetic variability among Anopheles species belonging to the Nyssorhynchus and Anopheles subgenera in the Amazon region}

\author{
Variabilidade genética entre espécies de Anopheles dos subgêneros Nyssorhynchus e Anopheles \\ da região Amazônica
}

Raquel Borges Moroni ${ }^{1}$, Juracy de Freitas Maia ${ }^{2}$, Wanderli Pedro Tadei ${ }^{2}$ and Joselita Maria Mendes dos Santos ${ }^{2}$

\begin{abstract}
Introduction: Isoenzymatic analyses were performed involving species of the Nyssorhynchus and Anopheles subgenera in order to estimate the intra and interspecies genetic variability. Methods: Mosquitoes were caught at different localities in the Amazon region. The collection and rearing of mosquitoes in the laboratory followed specific protocols. For the genetic variability analyses, the technique of horizontal electrophoresis on starch and starch-agarose gel with appropriate buffer systems was used. The alloenzyme variation was estimated using the Biosys-1 software. Results: Out of the 13 loci, eight were polymorphic. Anopheles nuneztovari presented the largest number of alleles per locus, while the smallest number was detected in Anopheles marajoara from Macapá. The largest number of polymorphic loci was found for Anopheles marajoara from Maruanum and the smallest for Anopheles benarrochi (Guayará Mirim). Anopheles darlingi (Macapá) presented the greatest heterozygosity $(\mathrm{Ho}=0.167 \pm 0.071)$, while the lowest heterozygosity ( $\mathrm{Ho}=0.045 \pm 0.019)$ was observed in Anopheles intermedius (Pacoval) of the subgenus Anopheles. Wright's F coefficient revealed considerable genetic structuring between the populations of Anopheles darlingi $(\mathrm{Fst}=0.110)$ and between the populations of Anopheles marajoara $(\mathrm{Fst}=0.082)$. Conclusions: Considering all the species studied, the genetic distance ranged from 0.008 to 1.114 . The greatest distance was between Anopheles mattogrossensis and Anopheles oswaldoi, while the smallest was between the Anopheles benarrochi populations.
\end{abstract}

Key-words: Nyssorhynchus. Anopheles. Genetic variability. Isoenzymes. Amazon.

\section{RESUMO}

Introdução: Análises isoenzimáticas foram realizadas envolvendo espécies dos subgêneros Nyssorhynchus e Anopheles para estimar a variabilidade genética intra e interespecífica. Métodos: Os mosquitos foram capturados em diferentes localidades da região Amazônica. A coleta e a criação dos mosquitos em laboratório foram conforme protocolos específicos. $\mathrm{Na}$ análise da variabilidade genética empregou-se a técnica de eletroforese horizontal em géis de amido e amido-agarose com sistemas tampões apropriados. A variação alozímica foi estimada pelo Programa Biosys-1. Resultados: Dos 13 loci, oito foram polimórficos. Anopheles nuneztovari apresentou o maior número de alelos por loco, sendo o menor detectado para Anopheles albitarsis (Macapá). O maior número de loci polimórficos foi detectado em Anopheles marajoara (Maruanum) e o menor, em Anopheles benarrochi (Guayará Mirim). Anopheles darlingi (Macapá) apresentou a maior heterozigosidade $\left(\mathrm{H}_{\mathrm{o}}=0,167 \pm 0.071\right)$ e a menor $\left(\mathrm{H}_{\mathrm{o}}=0,045 \pm 0.019\right)$ foi observada em Anopheles intermedius (Pacoval) do subgênero Anopheles. O coeficiente $\mathrm{F}$ de Wright evidenciou considerável estruturação genética entre populações de Anopheles darlingi $(\mathrm{Fst}=0,110)$ e entre as populações de Anopheles marajoara $(\mathrm{Fst}=0,082)$. Conclusões: Considerando todas as espécies estudadas, a distância genética variou de 0,008 a 1,144, onde a maior distância foi entre Anopheles mattogrossensis e Anopheles oswaldoi e a menor, entre as populações de Anopheles benarrochi.

Palavras-chaves: Nyssorhynchus. Anopheles. Variabilidade genética. Isoenzimas. Amazônia.

1. Department of Parasitology, Institute of Biological Sciences, Federal University of Amazon in Manaus, AM, Brazil. 2. Laboratory Vectors of Malaria and Dengue, National Institute of Research of the Amazon in Manaus, AM, Brazil.

Address To: Dra Raquel Borges Moroni. Depto de Parasitologia/UFAM. Av. Gal Rodrigo Otávio Jordão Ramos 3000, Bloco A, Coroado, Setor Sul, Campus Universitário, 69070-000 Manaus, AM, Brasil. Phone: 5592 3643-3066

e-mail: borgesraquel@hotmail.com

Received in 19/03/2009

Accepted in 11/05/2010

\section{INTRODUCTION}

Improved understanding of malaria transmission and control among humans can be achieved by developing studies on morphological and molecular characteristics. Among the molecular markers used in population genetic research, isoenzymes are used to estimate genetic variability, as well as for helping to elucidate problems that can occur in relation to morphological identification of species, especially given the existence of species complexes such as in the genus Anopheles ${ }^{1-5}$. The Anopheles albitarsis complex consists of six cryptic species ${ }^{6}$. $\mathrm{Li}$ and Wilkerson ${ }^{7}$ studied the species-specific variation of the ITS2 ribosomal DNA (rDNA) in order to identify the four species of the Albitarsis complex, and found complete correlation with the characteristics previously identified using random amplification of polymorphic DNA (RAPD). Merritt et $\mathrm{al}^{8}$ examined phylogenetic relationship within the Albitarsis complex using a region of the white gene and found consistency with RAPD analysis: four species were distinguished in the Albitarsis complex and a fourth intron was detected only in Anopheles marajoara. Alternative topology placed Anopheles marajoara as a sister to Anopheles albitarsis $\mathrm{B}$ and revealed a sister relation between Anopheles albitarsis sensu stricto and Anopheles deaneorum. Based on the complete sequence of the cytochrome oxidase I (COI) gene, together with support from maximum parsimony, maximum likelihood and Bayesian analyses, Lehr et al ${ }^{9}$ observed four members of the Anopheles deaneorum species that did not fit the sequences of the remaining Albitarsis complex species according to Bayesian topology, thus suggesting that these might represent a fifth species, Anopheles albitarsis E. Li and Wilkerson ${ }^{7}$ cloned and sequenced the ITS2 region of rDNA extracted from the four species belonging to the Albitarsis complex and, despite obtaining significant divergence in one clone from two individuals of Anopheles marajoara from Venezuela, they were unable to distinguish Anopheles albitarsis E from Anopheles marajoara. However, while studying specimens from Colombia, 
Brochero et $\mathrm{al}^{6}$ used the same rDNA region and a partial sequence of the white gene and detected the presence of a new species, denominated Anopheles albitarsis F. Differing from Anopheles marajoara, but in common with other species of the complex, Anopheles albitarsis $\mathrm{F}$ does not possess the fourth intron of the white gene. Numerous immunoradiometric assays (IRMA) and enzyme-linked immunosorbent assays (ELISA) have shown Anopheles albitarsis specimens infected with Plasmodium falciparum and Plasmodium vivax, thus placing it as a potential malaria vector ${ }^{10,11}$.

Studies on the genetic structure in Anopheles species have been conducted, notably on the Nyssorhynchus subgenus, since it includes the main vector species of human malaria in the neotropical region. Among these, Anopheles darlingi is the major malaria vector in Brazil and the most anthropophilic and endophagic in the Brazilian Amazon basin ${ }^{12}$. It is also a significant vector in other countries within its distribution range in South America, such as Peru, Colombia and Surinam ${ }^{13}$. The Anopheles triannulatus complex consists of three cryptic species: Anopheles triannulatus s.s., Anopheles halophylus and Anopheles triannulatus "C" $\mathrm{C}$. This complex occurs in Central and South America ${ }^{15}$ and has not been incriminated as a malaria vector, although specimens infected by Plasmodium vivax ${ }^{12,16}$ have been identified. Anopheles oswaldoi is largely distributed from the eastern region of South America up to Costa Rica in Central America. Together with Anopheles konderi, it forms a cryptic species complex. Anopheles nuneztovari is essentially a South American species, mainly in the Amazon region, and is an important vector in areas of Colombia, Venezuela and Peru; in Brazil it is considered to be a secondary vector. Cytogenetic, molecular and behavioral data indicate that this species forms a complex of two cryptic species ${ }^{17}$. Anopheles rangeli presents large distribution in South America, including Colombia, Ecuador, Guyana, Venezuela, Peru and Bolivia, and in Brazil it has been identified in the States of Amazonas, Acre, Rondônia, Pará and Roraima ${ }^{12,18}$. Anopheles benarrochi is considered to be predominantly zoophilic and not relevant to malaria transmission ${ }^{15}$. This species is found in Brazil, Venezuela and Colombia ${ }^{19}$.

Species of the subgenus Anopheles found in Brazil have not been identified as malaria vectors ${ }^{11}$, which is probably the reason for so few studies regarding the genetic structure of populations of these species ${ }^{20}$. Anopheles intermedius and Anopheles mattogrossensis, both belonging to the Anopheles subgenus, present wide geographic distribution. The former is found in Central and South America, and has been identified from Trinidad and Guyana up to Bolivia ${ }^{21}$. In Brazil, it is found throughout the country being abundant in the Amazon region, extending into the south, where it occupies coastal areas in the southern States $^{22}$. Anopheles mattogrossensis, is found in Bolivia, Brazil, Colombia, Peru and Venezuela ${ }^{23}$. In Brazil, it has been identified in the States of Acre, Amazonas, Roraima, Rondônia, Pará and Amapá ${ }^{24}$. No evidence exists that this species is involved in malaria transmission.

Considering the epidemiological importance of the Nyssorhynchus subgenus, the present work aimed to determine the genetic variability and differentiation of seven species of this subgenus and two of the subgenus Anopheles.

\section{METHODS}

\section{Species and collection locations}

The collection locations of Anopheles species of the Nyssorhynchus and Anopheles subgenera are shown in Figure 1. Adult females of the Anopheles subgenus were collected from areas surrounding homes and specimens of Nyssorhynchus subgenus were collected both around and inside homes, between 18:00 and 22:00. They were placed in individual plastic cups for oviposition. The eggs were reared up to the adult stage in the laboratory, in accordance with Santos et $\mathrm{a}^{25}$. Female adults and $4^{\text {th }}$ instar larvae were identified by means of the Consoli and Lourenço-de-Oliveira ${ }^{26}$ keys.

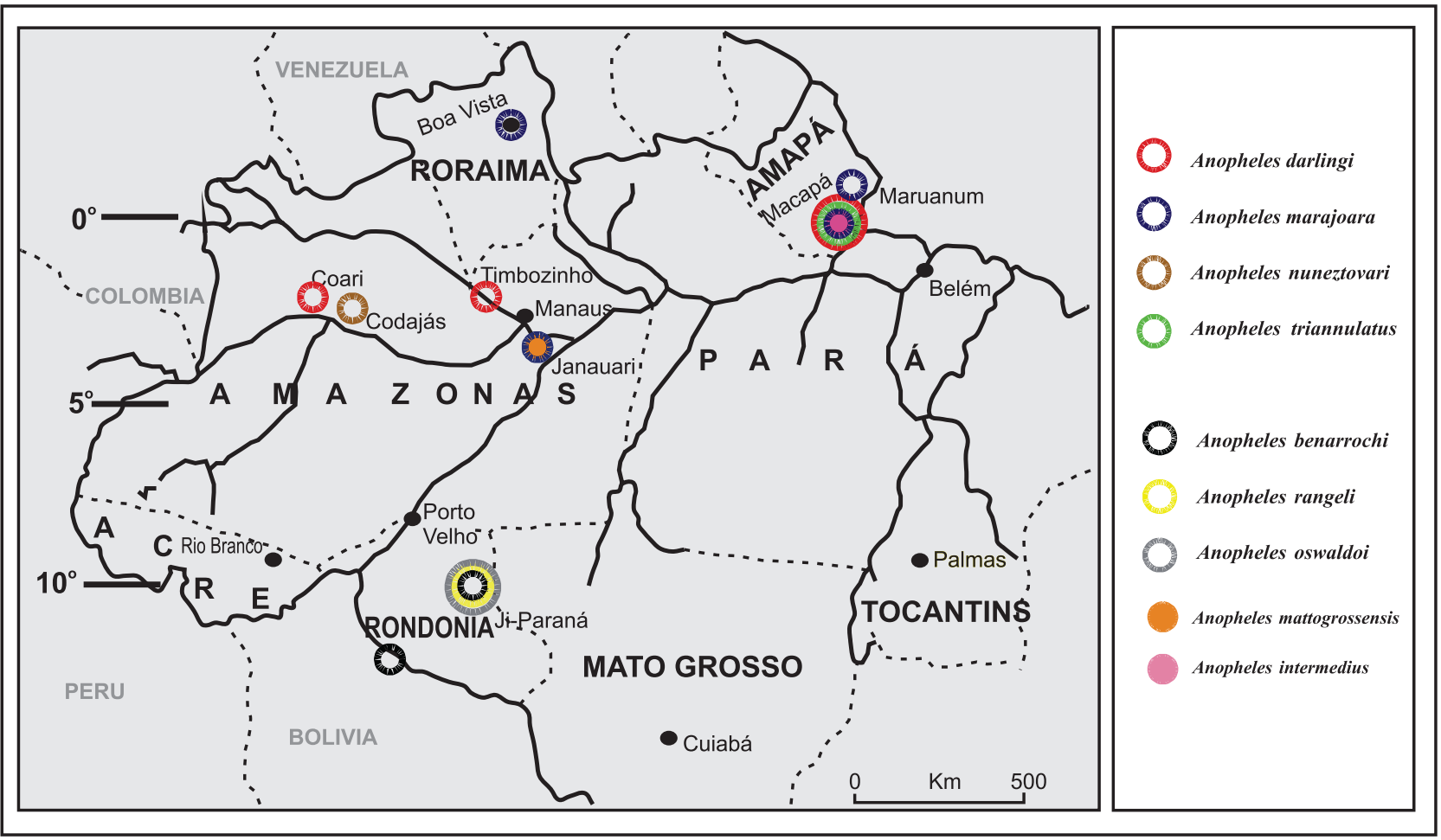

FIGURE 1 - Collection sites for Anopheles species belonging to the Nyssorhynchus and Anopheles subgenera, Amazon region. 


\section{Electrophoretic analysis}

Four $4^{\text {th }}$ instar larvae from each progeny for each enzyme system were used, with a mean of 75 larvae per population for each species. Of the eight enzyme systems studied, 13 loci were analyzed: esterase (EST1, EST5 -E.C.3.1.1.1), leucine aminopeptidase (LAP1,LAP2-E.C.3.4.1.1), isocitrate dehydrogenase (IDH 1 - E.C.1.1.1.42), phosphoglucomutase (PGM1 - E.C.2.7.5.1), phosphoglucose isomerase (PGI1 -E.C.5.3.1.9), hexokinase (HK1, HK2, HK3, HK4 - E.C.2.7.1.1), malic enzyme (ME1 -E.C.1.1.1.40) and malate dehydrogenase (MDH1 -EC 1.1.1.37). The larvae were homogenized in $20 \mu \mathrm{l}$ of $0.5 \%$ b-mercaptoethanol, and a Whatman No. $3\left(4.0 \mathrm{~cm}^{2}\right)$ filter paper was used to absorb supernatant for horizontal electrophoresis. Isoenzymes were separated using two types of electrophoretic support: starch gel, at a concentration of $12 \%$; and starch-agarose gel, at concentrations of $2 \%$ and $1 \%$. CA- $7^{27}$, modified Poulik $^{28}$ and TEMM buffer systems ${ }^{29}$ were used.

\section{Statistical analyses}

The alloenzyme variations were estimated using the Biosys- 1 software program ${ }^{30}$. The genetic distances were calculated in accordance with $\mathrm{Nei}^{31}$, and the UPGMA algorithm was used to generate a dendrogram.

\section{RESULTS}

Out of the 13 loci analyzed (Table 1), HK1, HK2, HK4 and PGI were monomorphic and the EST5 and PGM loci were polymorphic for all the species studied. EST1 was polymorphic, except in Anopheles benarrochi from Bolivia. LAP1 was polymorphic only in Anopheles marajoara from Maruanum, Anopheles intermedius and
Anopheles mattogrossensis, while LAP2 was monomorphic only in Anopheles darlingi from Timbozinho and Anopheles benarrochi from Bolivia. HK3 was polymorphic only in Anopheles marajoara from Macapá, Anopheles rangeli and Anopheles oswaldoi. $\mathrm{MDH} 1$ was polymorphic for the majority of the species, except for Anopheles triannulatus, Anopheles marajoara from Macapá, Anopheles darlingi from Timbozinho and Anopheles intermedius. The ME1 locus was polymorphic only in Anopheles triannulatus.

The chi-square test showed that $38 \%$ of the loci analyzed (EST1, EST5, PGM, LAP1 and LAP2) presented deviations from Hardy-Weinberg genetic equilibrium.

The mean number of alleles per locus varied from $1.5 \pm 0.2$ for Anopheles intermedius and Anopheles albitarsis from Macapá, to 2.2 \pm 0.1 for Anopheles mattogrossensis. Of the nine species analyzed, Anopheles marajoara from Maruanum was the most polymorphic ( $\mathrm{P}=53.8)$, while the least polymorphic species were Anopheles darlingi from Timbozinho and Anopheles benarrochi from Guayará Mirim ( $\mathrm{P}=30.8)$. Anopheles darlingi from Macapá revealed the highest value for heterozygosity $\left(\mathrm{H}_{\mathrm{o}}=0.165 \pm 0.071, \mathrm{H}_{\mathrm{e}}=0.172 \pm 0.061\right)$, while the lowest value was found for Anopheles intermedius from $\operatorname{Pacoval}\left(\mathrm{H}_{\mathrm{o}}=0.045 \pm 0.019, \mathrm{H}_{\mathrm{e}}=0.048 \pm 0.018\right)$ (Table 2).

The genetic distance values (D) ranged from 0.003 to 1.114 (Table 3). The greatest distance ( $\mathrm{D}=1.114)$ was between Anopheles (Nyssorhynchus) oswaldoi and Anopheles (Anopheles) mattogrossensis and the smallest $(\mathrm{D}=0.003)$ was between Anopheles (Nyssorhynchus) benarrochi from Bolivia and from Ji Paraná. For the ME1 locus, alleles $105,95,90$ and 85 were present only in species of the subgenus Nyssorhynchus, while the allele 100 was observed in species of both

TABLE 1- Frequencies of alleles at nine polymorphic loci in Anopheles species belonging to the Nyssorhynchus and Anopheles subgenera from the Amazon region.

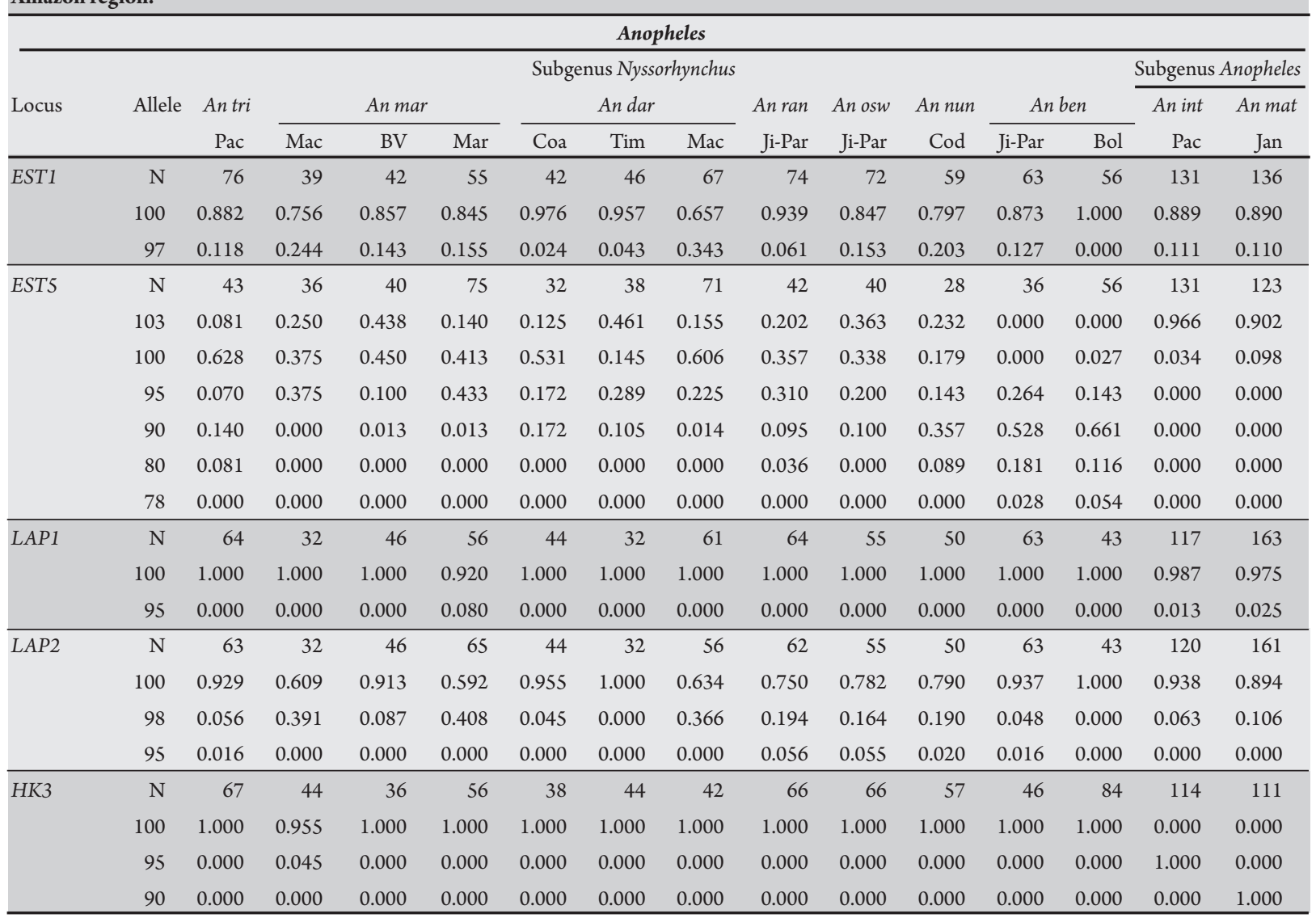

Continue.......... 
TABLE 1- Continuation.

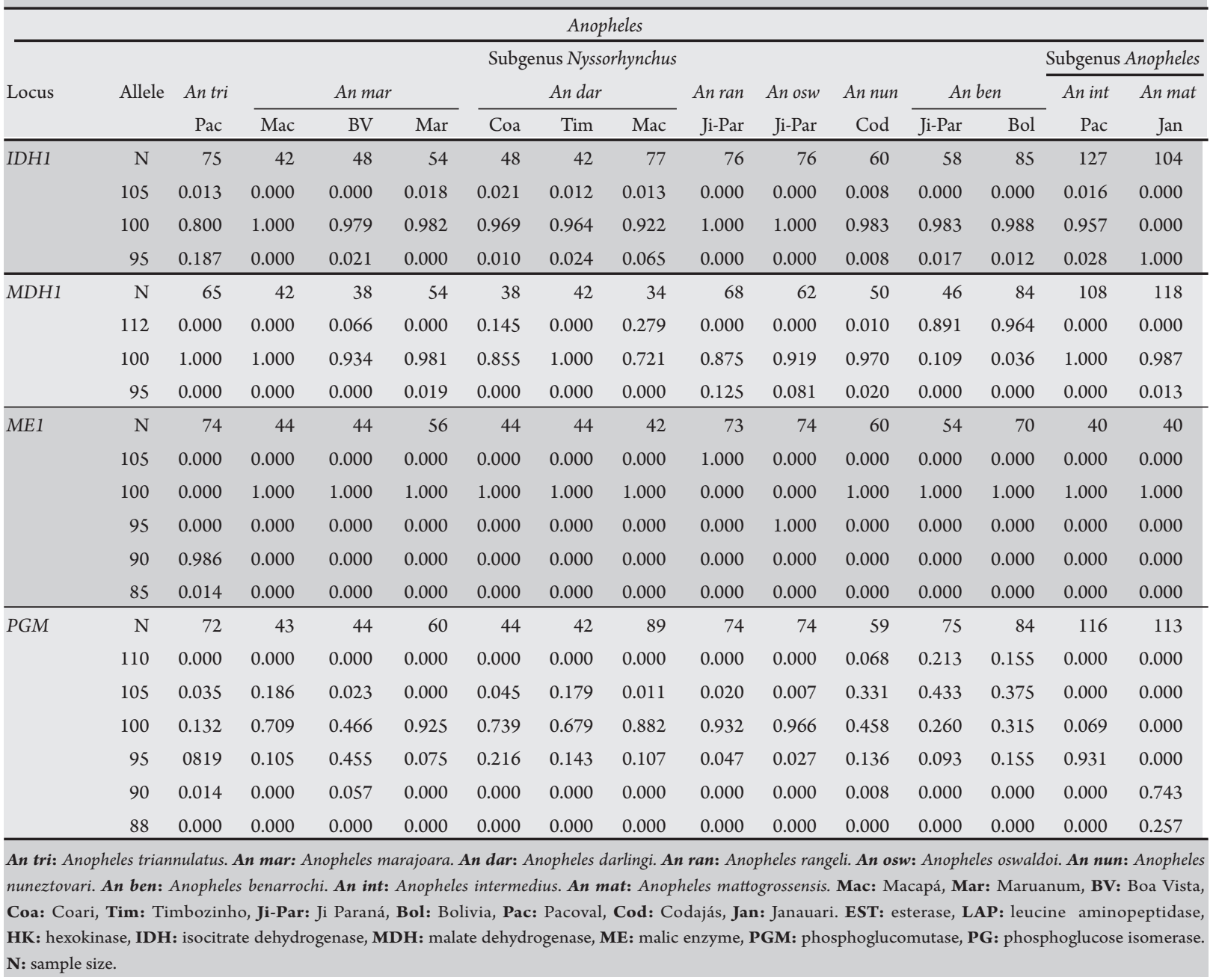

TABLE 2 - Genetic variability at thirteen loci in nine Anopheles species belonging to the Nyssorhynchus and Anopheles subgenera from the Amazon region.

\begin{tabular}{|c|c|c|c|c|c|c|}
\hline \multirow[b]{2}{*}{ Population } & \multirow{2}{*}{$\begin{array}{c}\text { Collection } \\
\text { sites }\end{array}$} & \multirow{2}{*}{$\begin{array}{c}\text { Mean sample } \\
\text { size/locus }\end{array}$} & \multirow{2}{*}{$\begin{array}{l}\text { Mean n. of } \\
\text { alleles/locus }\end{array}$} & \multirow{2}{*}{$\begin{array}{c}\text { Polymorphic } \\
\text { loci }(\%)^{*}\end{array}$} & \multicolumn{2}{|c|}{ Mean heterozygosity } \\
\hline & & & & & observed & expected $^{* *}$ \\
\hline An (Nys) triannulatus & Pacoval/AP & $66.8 \pm 2.6$ & $2.0 \pm 0.4$ & 46.2 & $0.092 \pm 0.037$ & $0.122 \pm 0.051$ \\
\hline$A n(N y s)$ marajoara & Macapá/AP & $39.6 \pm 2.1$ & $1.5 \pm 0.2$ & 38.5 & $0.140 \pm 0.077$ & $0.159 \pm 0.067$ \\
\hline An (Nys) marajoara & Boa Vista/RR & $41.4 \pm 1.4$ & $1.8 \pm 0.3$ & 46.2 & $0.136 \pm 0.063$ & $0.135 \pm 0.060$ \\
\hline An (Nys) marajoara & Maruanum/AP & $116.7 \pm 3.3$ & $1.7 \pm 0.2$ & 53.8 & $0.123 \pm 0.052$ & $0.133 \pm 0.058$ \\
\hline$A n(N y s)$ darlingi & Coari/AM & $40.7 \pm 1.4$ & $1.8 \pm 0.3$ & 46.2 & $0.079 \pm 0.034$ & $0.116 \pm 0.056$ \\
\hline$A n(N y s)$ darlingi & Timbozinho/AM & $41.4 \pm 1.3$ & $1.6 \pm 0.3$ & 30.8 & $0.086 \pm 0.049$ & $0.102 \pm 0.061$ \\
\hline$A n(N y s)$ darlingi & Macapá/AP & $86.3 \pm 14.9$ & $1.8 \pm 0.3$ & 46.2 & $0.165 \pm 0.071$ & $0.172 \pm 0.061$ \\
\hline An (Nys) rangeli & Ji Paraná/RO & $65.0 \pm 3.8$ & $1.8 \pm 0.3$ & 38.5 & $0.077 \pm 0.039$ & $0.123 \pm 0.061$ \\
\hline An (Nys) oswaldoi & Ji Paraná/RO & $63.2 \pm 4.0$ & $1.7 \pm 0.3$ & 38.5 & $0.117 \pm 0.055$ & $0.119 \pm 0.059$ \\
\hline An (Nys) nuneztovari & Codajás/AP & $51.7 \pm 3.0$ & $2.2 \pm 0.4$ & 46.2 & $0.128 \pm 0.059$ & $0.169 \pm 0.076$ \\
\hline An (Nys) benarrochi & Ji Paraná/RO & $53.8 \pm 3.4$ & $1.8 \pm 0.3$ & 46.2 & $0.133 \pm 0.062$ & $0.146 \pm 0.067$ \\
\hline$A n(N y s)$ benarrochi & Guayará-Mirim/Bolivia & $70.4 \pm 4.6$ & $1.7 \pm 0.4$ & 30.8 & $0.092 \pm 0.057$ & $0.103 \pm 0.065$ \\
\hline An (Ano) intermedius & Pacoval/AP & $112.2 \pm 6.3$ & $1.5 \pm 0.2$ & 46.2 & $0.045 \pm 0.019$ & $0.048 \pm 0.018$ \\
\hline An (Ano) mattogrossensis & Janauari/AM & $116.5 \pm 8.3$ & $1.5 \pm 0.1$ & 46.2 & $0.076 \pm 0.037$ & $0.078 \pm 0.034$ \\
\hline
\end{tabular}


TABLE 3 - Genetic identity (above diagonal) and distance coefficients (below diagonal) among fifteen populations of Anopheles (Nyssorhynchus and Anopheles subgenera) from the Amazon region.

\begin{tabular}{|c|c|c|c|c|c|c|c|c|c|c|c|c|c|c|}
\hline Species/ Collection sites & 1 & 2 & 3 & 4 & 5 & 6 & 7 & 8 & 9 & 10 & 11 & 12 & 13 & 14 \\
\hline An (Nys) triannulatus/Pacoval-AP & - & 0.761 & 0.804 & 0.751 & 0.789 & 0.774 & 0.715 & 0.671 & 0.668 & 0.685 & 0.603 & 0.602 & 0.446 & 0.421 \\
\hline An (Nys) marajoara /Macapá-AP & 0.273 & & 0.978 & 0.996 & 0.890 & 0.891 & 0.894 & 0.811 & 0.722 & 0.800 & 0.790 & 0.772 & 0.575 & 0.569 \\
\hline An (Nys) marajoara/Maruanum-AP & 0.287 & 0.004 & 0.034 & - & 0.891 & 0.855 & 0.896 & 0.818 & 0.727 & 0.788 & 0.777 & 0.763 & 0.547 & 0.549 \\
\hline An (Nys) darlingi/Coari-AM & 0.236 & 0.117 & 0.105 & 0.115 & - & 0.986 & 0.979 & 0.729 & 0.814 & 0.891 & 0.734 & 0.734 & 0.497 & 0.488 \\
\hline An (Nys) darlingi/Timbozinho-AM & 0.257 & 0.115 & 0.106 & 0.122 & 0.014 & - & 0.958 & 0.726 & 0.816 & 0.898 & 0.723 & 0.717 & 0.527 & 0.521 \\
\hline An (Nys) darlingi/Macapá-AP & 0.287 & 0.112 & 0.131 & 0.110 & 0.021 & 0.043 & - & 0.712 & 0.803 & 0.870 & 0.712 & 0.702 & 0.447 & 0.456 \\
\hline An (Nys) rangeli/Ji Paraná-RO & 0.398 & 0.209 & 0.224 & 0.201 & 0.316 & 0.320 & 0.340 & - & 0.824 & 0.798 & 0.801 & 0.793 & 0.479 & 0.393 \\
\hline An (Nys) oswaldoi/Ji Paraná-RO & 0.403 & 0.326 & 0.336 & 0.320 & 0.206 & 0.204 & 0.219 & 0.194 & - & 0.889 & 0.705 & 0.698 & 0.406 & 0.319 \\
\hline An (Nys) nuneztovari/Codajás-AP & 0.378 & 0.223 & 0.225 & 0.238 & 0.116 & 0.108 & 0.139 & 0.225 & 0.117 & - & 0.829 & 0.817 & 0.499 & 0.407 \\
\hline An (Nys) benarrochi/Ji Paraná-RO & 0.506 & 0.236 & 0.221 & 0.252 & 0.309 & 0.324 & 0.340 & 0.222 & 0.350 & 0.187 & - & 0.997 & 0.496 & 0.410 \\
\hline An $(\mathrm{Nys})$ benarrochi/Guayará-Mirim-Bolivia & 0.507 & 0.259 & 0.230 & 0.270 & 0.309 & 0.333 & 0.354 & 0.232 & 0.359 & 0.202 & 0.003 & - & 0.496 & 0.407 \\
\hline An (Ano) mattogrossensis/Janauari-AM & 0.864 & 0.564 & 0.505 & 0.600 & 0.718 & 0.651 & 0.784 & 0.934 & 1.144 & 0.898 & 0.891 & 0.899 & 0.628 & \\
\hline
\end{tabular}

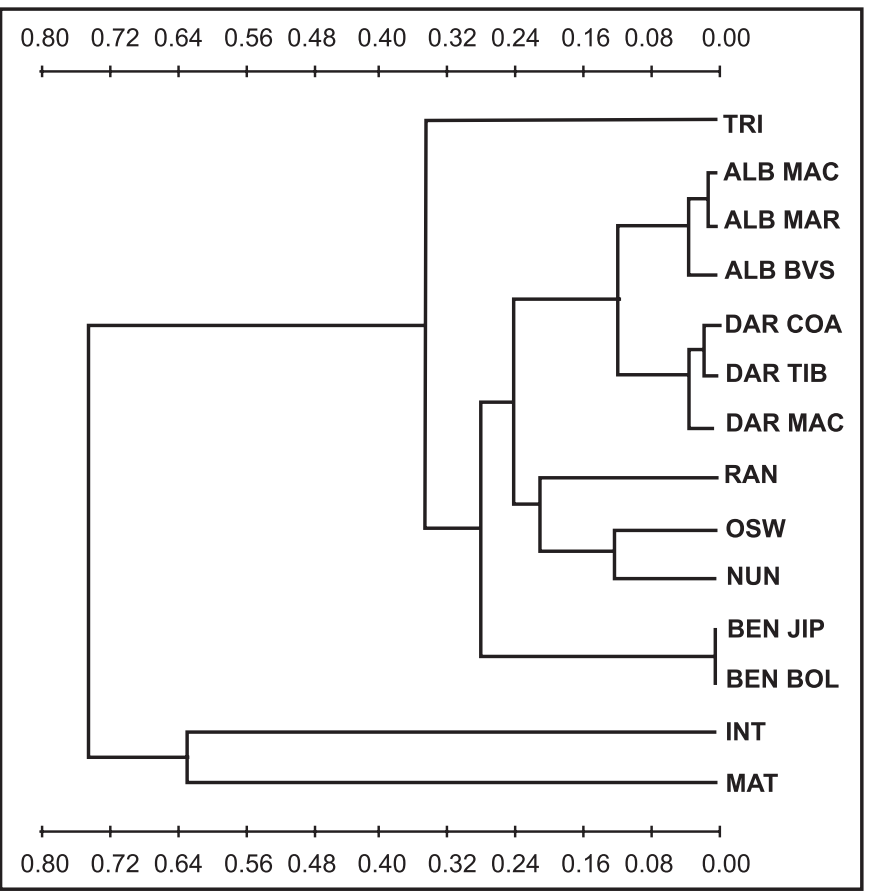

FIGURE 2 - UPGMA dendrogram for nine Anopheles species based on their genetic distances values (Nei, 1978). Unweighted method of population grouping using arithmetic mean (UPGMA). Species: TRI: Anopheles triannulatus. ALB: Anopheles marajoara. DAR: Anopheles darlingi. RAN: Anopheles rangeli. OSW: Anopheles oswaldoi. NUN: Anopheles nuneztovari. BEN: Anopheles benarrochi. INT: Anopheles intermedius. MAT: Anopheles mattogrossensis. Collection locations: MAC: Macapá. MAR: Maruanum. BVS: Boa Vista. COA: Coari. TIB: Timbozinho. JIP: Ji Paraná. BOL: Bolivia. Cophenetic correlation $=0.930$.

subgenera. Alleles 110 and 105 of the PGM1 locus were detected in the subgenus Nyssorhynchus and allele 88 was only observed in Anopheles mattogrossensis of the subgenus Anopheles. For the locus PGI1, alleles 95 and 90 were detected in species of the subgenus Nyssorhynchus. Allele 100 of the HK1 and HK2 loci was detected in the subgenus Nyssorhynchus, and in the subgenus Anopheles, allele 95 was observed in Anopheles intermedius and allele 90 in Anopheles mattogrossensis. For the locus HK4, only the allele 105 was observed in Anopheles intermedius. Allele 100 was detected in Anopheles triannulatus, Anopheles marajoara, Anopheles darlingi and Anopheles mattogrossensis, and allele 95 was observed in Anopheles rangeli, Anopheles oswaldoi, Anopheles nuneztovari, Anopheles benarrochi and Anopheles mattogrossensis. For the PGI1 locus, allele 100 was observed in all species with the exception of Anopheles marajoara, Anopheles rangeli and Anopheles oswaldoi, in which allele 95 was detected. Allele 90 was observed only in Anopheles triannulatus (Table 1).

Based on the genetic distance values, the species were separated into four groups: three in the subgenus Nyssorhynchus and one in the subgenus Anopheles. The first group was composed of Anopheles marajoara and Anopheles darlingi (Argyritarsis section). Anopheles darlingi from Coari and Anopheles marajoara from Maruanum presented the highest identity value $(\mathrm{I}=0.891)$, thus indicating low genetic differentiation. The second group was composed of Anopheles benarrochi (Albimanus section) and the third included Anopheles rangeli, Anopheles oswaldoi and Anopheles nuneztovari (Albimanus section). The fourth group was composed of Anopheles mattogrossensis and Anopheles intermedius (Figure 2).

\section{DISCUSSION}

Several studies involving the electrophoretic patterns of isoenzymes have been used for ontogeny analysis ${ }^{32}$, as well as for analysis of genetic variability and differentiation in Anopheles populations ${ }^{2,20,33}$. Isoenzyme analysis associated with morphological and biochemical studies has contributed towards identifying species complexes, which are common among anopheline mosquitoes, and has been used to differentiate malaria vector and nonvector species ${ }^{33}$, thus improving the current understanding of the mechanisms of malaria transmission and control ${ }^{20}$. Given that the subgenus Nyssorhynchus contains the principal malaria transmission species in Brazil, this subgenus has been investigated in general with the aim of achieving greater understanding of the genetic structure of its species and the dynamics of malaria transmission, as well as the possible mechanisms responsible for the vector capacity of the species involved ${ }^{33}$. In contrast, in the subgenus Anopheles, which does not contain species involved in malaria transmission in Brazil, such studies are at an incipient stage $\mathrm{e}^{20,34}$. 
The variation observed in the percentages of polymorphic loci corroborate data obtained by Fritz et $\mathrm{a}^{35}$, when studying Anopheles rangeli, Anopheles nuneztovari and Anopheles trinkae originating from Venezuela, Ecuador, Brazil and Bolivia $\left(\mathrm{P}=20.3\right.$ - 58.3\%). Scarpassa et al ${ }^{17}$ analyzed 13 isoenzyme loci in populations from Colombia and Brazil and also observed Anopheles nuneztovari polymorphism levels ( $\mathrm{P}=31.3-56.6 \%)$ similar to those obtained in the present study. According to our data, Rodrigue $^{36}$ detected low polymorphism for Anopheles intermedius and Anopheles mattogrossensis ( $\mathrm{P}=35.3$ and $47.1 \%$, respectively). The low polymorphism and heterozygosity levels obtained for these species may be associated with low selection pressure because of their inability to cause Plasmodium infection. The most polymorphic species in the present study were Anopheles triannulatus, Anopheles darlingi and Anopheles marajoara, thus corroborating the results obtained by Santos et $\mathrm{a}^{20}$.

We found genetic variability similar to other species of the same subgenera $^{33,35}$. However, despite the high polymorphism presented, the heterozygosity levels were considered low for Anopheles marajoara from Maruanum $\left(\mathrm{H}_{\mathrm{o}}=0.123 \pm 0.052, \mathrm{H}_{\mathrm{e}}=0.133 \pm 0.058\right)$. A high number of alleles per locus was observed for species of the subgenus Nyssorhynchus, with Anopheles nuneztovari presenting the highest value (2.2 \pm 0.4$)$. Low values were detected for Anopheles intermedius and Anopheles mattogrossensis, which are both species of the subgenus Anopheles $(1.5 \pm 0.2$ and $1.5 \pm 0.1)$. This shows the wide genetic variability in the Anopheles species and suggests that the variability is related to the innate population structure: mutation, preferential mating and selection or genetic drift.

The genetic distance values calculated for the Anopheles marajoara ( $\mathrm{D}=0.004-0.034)$ and Anopheles darlingi populations $(\mathrm{D}=0.014-0.043)$ argues in favor of some differentiation. However, this was not observed in Anopheles benarrochi populations, in which the genetic distance values were very low $(\mathrm{D}=0.003)$. Other studies have also found strong similarities among populations of different Anopheles species. Santos et $\mathrm{al}^{33}$ obtained distance values from 0.010 to 0.024 for Anopheles darlingi populations from the Amazon region. Likewise, Manguin et $\mathrm{a}^{37}$ reported a range of genetic distances for this species in South America, from 0.005 to 0.024 .

The genetic distances observed among Anopheles marajoara populations belonging to the Anopheles albitarsis complex $(\mathrm{D}=0.004-0.034)$ differed from those reported by Narang et $\mathrm{al}^{38}$ in populations of this complex $(\mathrm{D}=0.074-0.406)$. We found genetic distances among Anopheles oswaldoi, Anopheles nuneztovari and Anopheles rangeli ranging from 0.117 to 0.194 , thus corroborating the results of Trindade ${ }^{39}$, who obtained a genetic distance between Anopheles rangeli and Anopheles nuneztovari of 0.182 . However, higher values between Anopheles rangeli and Anopheles nuneztovari were obtained by Fritz et $\mathrm{al}^{35}$, in studying populations from Venezuela, Ecuador, Brazil and Bolivia ( $\mathrm{D}=0.319$ - 0.419).

The genetic distance values obtained between Anopheles triannulatus and Anopheles darlingi, Anopheles albitarsis, Anopheles intermedius and Anopheles mattogrossensis were generally lower $(\mathrm{D}=0.287 ; 0.287 ; 0.807$ and 0.864 , respectively) than those obtained previously ${ }^{20}$ in analyses on genetic distances among populations of the same species $(D=0.524,0.399,0.989$ and 0.789 , respectively). Moreover, previous studies ${ }^{4}$ on Anopheles triannulatus populations in the Brazilian Amazon region revealed much smaller genetic distances $(\mathrm{D}=0.011-0.052)$. These data partially corroborate those reported by Sallum et $\mathrm{al}^{40}$, which were based on molecular characteristics, and by Harbach ${ }^{41}$ based on morphological and molecular studies.
Considering the subgenus Nyssorhynchus, our data revealed genetic similarity among the Anopheles darlingi and Anopheles albitarsis populations, while the Anopheles benarrochi and Anopheles triannulatus populations presented great divergence (Figure 2). In part, these data disagree with those reported by Sallum et $\mathrm{al}^{42}$, who grouped Anopheles albitarsis and Anopheles triannulatus into the same cluster and separated these from Anopheles darlingi, based on morphological characteristics and on another study conducted by Sallum et $\mathrm{al}^{40}$, using mitochondrial and ribosomal DNA sequences. However, Santos et al ${ }^{20}$ studied five Anopheles species based on isoenzyme variation and reported results similar to those presented in this work.

In general, the species of the subgenus Nyssorhynchus showed greater variability than was shown by the species belonging to the subgenus Anopheles, thus corroborating the results obtained by Sallum et $\mathrm{al}^{42}$ from studies on morphological characteristics. The low heterozygosity found in Anopheles mattogrossensis and Anopheles intermedius populations can be related to their specialized niches, in spite of showing wide geographic distribution. However, there is a need to amplify the enzyme systems used and define more conservative molecular markers for future studies, in order to the improve current understanding of the taxonomic position of species belonging to the subgenera Nyssorhynchus and Anopheles.

\section{ACKNOWLEDGMENTS}

The authors are grateful to the technicians of the Malaria and Dengue Vector Laboratory/National Institute Research of Amazonia (INPA) for collecting and identifying the mosquitoes used in this work, and to the National Council for Scientific and Technological Development $(\mathrm{CNPq})$ for providing a grant for this work.

\section{CONFLICT OF INTEREST}

The authors declare that there is no conflict of interest.

\section{FINANCIAL SUPPORT}

Project North for Post-Graduation and Research (PNOPG), Institutional Research Project 3680 (PPI) and National Council for Scientific and Technological Development (CNPq/Rede Malaria).

\section{REFERENCES}

1. Rosa-Freitas MG, Deane LM, Momen H. A morphological, isoenzymatic and behavioural study of ten populations of Anopheles (Nyssorhynchus) albitarsis LynchArribalzaga, 1878 (Diptera: Culicidae) including from the type-locality Baradero, Argentina. Mem Inst Oswaldo Cruz 1990; 85:275-289.

2. Carvalho-Pinto CJ, Lourenço-de-Oliveira R. Isoenzimatic analysis of four Anopheles (Kertezia) bellator Dyar \& Kanb (Diptera: Culicidae) populations. Mem Inst Oswaldo Cruz 2003; 98:1045-1048.

3. Carvalho-Pinto CJ, Lourenço-de-Oliveira R. Isoenzimatic analysis of four Anopheles (Kertezia) (Diptera: Culicidae) populations of Brazil. Mem Inst Oswaldo Cruz 2004; 99:471-475.

4. Santos JMM, Maia JF, Tadei WP. Differentiation and genetic variability in natural populations of Anopheles (N.) triannulatus (Neiva\& Pinto, 1922) of Brazilian Amazonia. Braz J Biol 2004; 64:327-336.

5. Wilkerson RC, Gaffigan TV, Lima JB. Identification of species related to Anopheles (Nysssorhynchus) albitarsis by random amplified polymorphic DNA-polymerase chain reaction (Diptera: Culicidae). Mem Inst Oswaldo Cruz 1995; 90:721-732. 
6. Brochero HHL, Li C, Wilkerson RC. A newly recognized species in the Anopheles (Nyssorhynchus) albitarsis complex (Diptera: Culicidae) from Puerto Carreno, Colombia. Am J Trop Med Hyg 2007; 76:1113-1117.

7. LiC, Wilkerson RC. IntragenomicrDNAITS2 variation in the Neotropical Anopheles (Nyssorhynchus) albitarsis complex (Diptera: Culicidae). J Hered 2007; 98:51-59.

8. Merritt TJS, Young CR, Vogt RG, Wilkerson RC, Quattro JM. Intron retention identifies a malaria vector within the Anopheles (Nyssorhynchus) albitarsis complex (Diptera: Culicidae). Mol Phyl Evol 2005; 35:719-724.

9. Lehr MA, Kilpatrick CW, Wilkerson RC, Conn JE. Cryptic species in the Anopheles (Nyssorhynchus) albitarsis (Diptera: Culicidae) complex: incongruence between Random Amplified Polymorphic DNA-Polymerase Chain Reaction identification and analysis of mitochondrial DNA COI gene sequences. Ann Entomol Soc Am 2005; 98:908-917.

10. Branquinho MS, Lagos CB, Rocha RM, Natal D, Barata JM, Cochrane AH, et al. Anophelines in the state of Acre, Brazil, infected with Plasmodium falciparum, P. vivax, the variant $P$. vivax VK247 and P. malariae. Trans R Soc Trop Med Hyg 1993; 87:391-394.

11. Tadei WP, Dutary-Thatcher B. Malaria vectors in the Brazilian Amazon: Anopheles of the subgenus Nyssorhynchus. Rev Inst Med Trop São Paulo 2000; 42:87-94.

12. Tadei WP, Santos JMM, Scarpassa VM, Rodrigues IB. Incidência, distribuição e aspectos ecológicos de espécies de Anopheles (Diptera: Culicidae), em regiões naturais e sob impacto ambiental da Amazônia brasileira. In: Ferreira EJG, Santos GM, Leão ELM, Oliveira LA, editores. Bases Científicas para Estratégias de Preservação e Desenvolvimento da Amazônia. Instituto Nacional de Pesquisas da Amazônia. 1a edição. Vol 2. Editora INPA. Manaus; 1993.

13. Vittor A, Gilman R, Tielsch J, Glass G, Shields T, Lozano W, et al. The effect of deforestation on the human-biting rate of Anopheles darlingi, the primary vector of Falciparum malaria in the Peruvian Amazon. Am J Trop Med Hyg 2006; 74:3-11.

14. Silva-do-Nascimento T, Wilkerson RC, Lourenço-de-Oliveira R, Monteiro FA. Molecular confirmation of the specific status of Anopheles halophylus (Diptera: Culicidae) and evidence of a new criptic species within An. triannulatus in Central Brazil. J Med Entomol 2006; 43:455-459.

15. Faran ME, Linthicum KJ. A handbook of the Amazonian species of Anopheles (Nyssorhynchus) (Diptera, Culicidae). Mosq Syst 1983; 113:1-81.

16. Tadei WP, Santos JMM, Costa WLS, Scarpassa VM. Biologia de anofelinos amazônicos XII. Ocorrência de espécies de Anopheles, dinâmica de transmissão e controle da malária na zona urbana de Ariquemes (Rondônia). Rev Inst Med Trop São Paulo 1988; 30:221-251.

17. Scarpassa VM, Tadei WP, Suarez MF. Population structure and genetic divergence in Anopheles nuneztovari (Diptera: Culicidae) from Brazil and Colombia. Am J Trop Med Hyg 1999; 60:1010-1018.

18. Ferreira E. Distribuição geográfica dos anofelinos no Brasil e sua relação com o estudo atual da erradicação da malária. Rev Bras Malar D Trop 1964; 16:329-348.

19. Schoeler GB, Flores-Mendoza R, Fernández R, Davila JR, Zuzak M. Geografica distribution of Anopheles darlingi (Diptera: Culicidae) in the Amazon basin region of Perú. J Am Mosq Control Assoc 2003; 19:286-296.

20. Santos JMM, Maia JF, Tadei WP, Rodriguez GAD. Isoenzymatic Variability among five Anopheles species belonging to the Nyssorhynchus and Anopheles subgenera of the Amazon Region, Brazil. Mem Inst Oswaldo Cruz 2003; 98:247-253.

21. Morales-Ayala F. A list of the mosquitoes of Peru (Diptera: Culicidae). Mosq Syst $1971 ; 3: 138-145$

22. Deane LM. Malaria vectores in Brazil. Mem Inst Oswaldo Cruz 1986; 81:5-14.

23. Garcia M, Ronderos RA. Mosquitos de la República Argentina. 1. Tribu Anophelini (Diptera-Culicidae-Culicinae). An Com Inv Cient Prov Bs As 1962; 3:103-112.

24. Forattini OP. Entomologia Médica. Faculdade de Higiene e Saúde Pública. $1^{a}$ edição. Vol 1. São Paulo; 1962.

25. Santos JMM, Contel EPB, Kerr WE. Biologia de anofelinos amazônicos. Ciclo biológico, postura e estádios larvais de Anopheles darlingi Root, 1926 (Diptera: Culicidae) da Rodovia Manaus/Boa Vista. Acta Amazonica 1981; 11:789-797.

26. Consoli RAGB, Lourenço-de-Oliveira R. Principais Mosquitos de Importância Sanitária no Brasil. Fundação Oswaldo Cruz. Rio de Janeiro; 1994.

27. Steiner WWM, Joslyn DJ. Electrophoretic techniques for the genetic studies of mosquitoes. Mosq News 1979; 39:35-54.
28. Contel EPB. Variabilidade Protéica em Populações Naturais de Abelhas da Amazônia. [Tese]. Ribeirão Preto (SP): Universidade de São Paulo; 1980.

29. Harris H, Hopkinson DA. Handbook of Enzyme Electrophoresis in Human Genetics. North-Holland Publishing Co, Amsterdam; 1976.

30. Swofford DL, Selander RK. BIOSYS-1: a FORTRAN program for the comprehensive analysis of electrophoretic data in population genetics and systematics. J Hered 1981; 72:281-283.

31. Nei M. Estimation of average heterozygosity and genetic distance from a small number of individuals. Genetics 1978; 89:583-590.

32. Santos JMM, Contel EPB, Kerr WE. Biology of Amazonian mosquitoes. III. Esterases isozymes in Anopheles darlingi. Acta Amazonica 1985; 15:167-177.

33. Santos JMM, Lobo JA, Tadei WP, Contel EPB. Intrapopulational genetic differentiation in Anopheles (N.) darlingi Root, 1926 (Diptera: Culicidae) in the Amazon region. Gen Mol Biol 1999; 22: 325-331.

34. Santos JMM, Rodriguez GAD, Maia JF, Tadei WP. Variability and genetic differentiation among Anopheles (Ano.) intermedius Chagas, 1908 and Anopheles (Ano.) mattogrossensis Lutz \& Neiva, 1911 (Diptera: Culicidae) from the Brazilian Amazon. Mem Inst Oswaldo Cruz 2005; 100:531-537.

35. Fritz GN, Bermudez H, Seawright JA. Genetic differentiation and diagnostic loci of Anopheles nuneztovari, An. trinkae, and An. rangeli (Diptera: Culicidae) J Med Entomol 1995; 32:663-672.

36. Rodriguez GAD. Padrões Isoenzimáticos e Variabilidade Genética em Anopheles (Anopheles) intermedius Chagas, 1908 e Anopheles (Anopheles) mattogrossensis Lutz \& Neiva, 1911 (Diptera: Culicidae) da Amazônia Brasileira [Dissertação]. Manaus (AM): Instituto Nacional de Pesquisas da Amazônia; 1998.

37. Manguin S, Wilkerson RC, Conn JE, Rubio-Palis Y, Danoff-Burg JA, Roberts DR Population structure of the primary malaria vector in South America Anopheles darlingi, using isozyme, random amplified polymorphic DNA, internal transcribed spacer 2, and morphologic markers. Am J Trop Med Hyg 1999; 60:364-376.

38. Narang SK, Klein TA, Perera OP, Lima JB, Tang AT. Genetic evidence for the existence of cryptic species in the Anopheles albitarsis complex in Brazil: Allozymes and mitochondrial DNA restriction fragment length polymorphisms. Biochem Gen 1993; 31:97-112.

39. Trindade DB. Diferenciação genética entre Anopheles (Nyssorhynchus) rangeli Gabaldón, Cova-Garcia \& Lopes, 1940, A. (N). nuneztovari Gabaldón, 1940 e A. (N) dunhami Causey, 1945 (Diptera: Culicidae) da Amazônia Brasileira. [Dissertação]. Manaus (AM): Instituto Nacional de Pesquisas da Amazônia; 2001.

40. Sallum MAM, Schultz TR, Foster PG, Aronstein K, Wirtz RA, Wilkerson RC Phylogeny of Anophelinae (Diptera Culicidae) based on nuclear ribosomal and mitochondrial DNA sequences. Syst Entomol 2002; 27:361-382.

41. Harbach RE. The classification of genus Anopheles (Diptera: Culicidae): a working hypothesis of phylogenetic relationships. Bull Entomol Res 2004; 94:537-553.

42. Sallum MAM, Schultz TR, Wilkerson RC. Phylogeny of Anophelinae (Diptera Culicidae) based on morphological characters. Ann Entomol Soc Am 2000;93:745-775. 